Copyright (C2015

Australian and New Zealand Journal of European Studies http://www.eusanz.org/ANZJES/index.htm/

Vol.6(2)-7(1)

ISSN 1837-2147 (Print)

ISSN 1836-1803 (Online)

\title{
A Transnational Challenge - Energy Security
}

\author{
Rita Parker \\ University of New South Wales, Canberra \\ r.parker@adfa.edu.au
}

\begin{abstract}
Transnational challenges have added a level of complexity to international and national security as the geopolitical landscape adjusts and responds. Such challenges transcend individual borders to involve other nation-states regardless of whether they are willing or unwilling actors. One such transnational challenge is energy security and the resilience of the energy supply system. While energy is generally considered as a national issue associated with meeting the internal needs of a civil society, it is also part of a wider dynamic global system that is vulnerable to a number of factors and is a major influence in framing foreign policy stances. This paper addresses the linkage between energy security and foreign policy at both the state and international levels. It does this by examining some of the issues and challenges associated with energy as a transnational security issue and the ways it affects relations between nation-states. The focus of this paper is on petroleum-based fuel and gas, and on the security and resilience of the energy supply system. Given the ongoing dependence on these traditional forms of energy, it is argued that these energy systems need to be resilient so that, in turn, civil society is resilient and human security is enhanced. The paper explores some of the issues for the European Union (EU) including the resilience of its associated energy systems. The paper also considers issues that enhance or inhibit the resilience of the energy system with particular reference to the EU.
\end{abstract}

Keywords: Energy Security, European Union, Resilience, Transnational Issues, Vulnerabilities.

\section{Introduction}

"For more than a century, energy, politics, and power have been clearly intertwined as a force in international security". Indeed the decision before WWI by then First Lord of the Admiralty Winston Churchill to convert the British Royal Navy from coal to oil is an overt example of linking energy and security. In doing so, Churchill recognised there were risks, and vulnerabilities, associated with such a decision. In Churchill's memoirs ${ }^{2}$ he wrote:

oil supplies of the world were in the hands of vast oil trusts under foreign control. To commit the navy irrevocably to oil was indeed to take arms against a sea of troubles. ... If we overcame the difficulties and surmounted the risks, we should be able to raise the whole power and efficiency of the navy to a

${ }^{1}$ C. Pascual, E. Zambetakis, (2008), The Geopolitics of Energy, Brookings Institution Press, Washington DC, p.33.

${ }^{2}$ W. S. Churchill, (1923), The World Crisis, Scribner Books, New York, Vol 1, pp. 133-136. 
definitely higher level; better ships, better crews, higher economies, more intense forms of war power - in a word, mastery itself was the prize of the venture.

Such a decision inexorably linked energy policy with national security within the wider geopolitical system. Other navies followed with similar conversions ${ }^{3}$ with the consequence that energy security became a foremost consideration for nation-states in the decades that followed to the present day. Over time and with the increasing activities of some non-state actors, energy and its security have increased in importance as a foreign policy issue in the security agendas of nation-states. Indeed, it could be argued that energy security influenced foreign policy decisions and relations between nation-states and will continue to frame political, security and foreign policy agendas for the remainder of the 21st century.

There are many forms of conventional and unconventional energy including oil, coal, electricity, gas, bio fuels solar, wind and nuclear. However, this paper is focused mainly on petroleum-based fuel and on gas security and the resilience of those energy systems.

\section{Energy security}

Energy security relates to the ability of an energy user, nation-state or individual to have ready and affordable access to an appropriate form of energy as and when required. This is a complex issue which has an impact on global, regional, national and human security. It is recognised at the outset that energy security means different things to different actors. This difference in perception is influenced by a number of factors, including the way the separate terms of 'security' and 'energy security' are framed. For example, in international relations the realist view of security is a result of power, whereas the idealist school of thought is that security can be described as a consequence of peace and cooperation.

The way the term 'energy security' is framed depends on factors such as whether a nation-state is a net importer or exporter of energy, its geographic location, degree of economic stability, whether its claims to energy resources are challenged, and access to energy options. The way energy security is interpreted also depends on which actor or discipline is framing the concept, and which key biases prevail. For example, as explained by Comolli4, in international relations it generally refers to the politics of energy and resource management, whereas economists would argue that energy supplies are determined by market forces and therefore not a matter of security. A perspective which is less likely to be contested is that energy provides the foundation for the stability of a nation-state and the wellbeing of its civil society. The way energy security is defined and understood in the literature and by different actors varies and to a large extent it is context dependent. For example, Sovacool 5 defines energy security as "equitably providing available, affordable, reliable, efficient, environmentally benign, proactively governed, and socially acceptable energy

3E. J. Dahl, (2000), 'From Coal to Oil', in Joint Force Quarterly, Winter Volume, pp 50-56, p. 50.

4V. Comolli, (2010), 'Energy Security', in B. Giegerich (Ed), Europe and Global Security, Routledge, Oxford, pp177-196, p.177.

5B. K. Sovacool, (2012), Energy security: challenges and needs. WIREs Energy Environ., Vol 1, Issue 1, pp. 51-59. 
services to end users". Indeed Sovocool ${ }^{6}$ provides forty-five definitions of energy security with the assumption that the energy security applies primarily to the nation-state, while Winzer 7 , on the other hand, provides thirty-five separate definitions of security of supply. Definitions also vary regarding where their emphasis is placed. The International Energy Agency's (IEA) definition of energy security emphasises price and the environment, "the uninterrupted physical availability at a price which is affordable, while respecting environmental concerns"8. Yergin on the other hand takes a geopolitical perspective and defines it as, "lodged in the larger relations among nations and how they interact with one another". 9

For many policy and decision-makers, the term 'energy security' is framed in economic terms and refers primarily to the ability of nation-states to have uninterrupted access to energy at affordable prices without significant and unexpected price fluctuations. However, that interpretation is more suitable to net importing nation-states rather than net exporters. For producing nation-states, energy security can also refer to the absence of risks or threats that might endanger or jeopardise the ability to control resources, including extraction, production, processing, transportation and storage of energy. This distinction is at the heart of the challenges faced by the European Union to achieve a common energy policy that is relevant to all twenty-eight member states each of which has its own specific polices and agendas.

Brown et al provide the most appropriate definition for this paper as "energy security refers to a resilient energy system"10. This definition is further expanded by drawing on the UK Energy Research Centre ${ }^{11}$ working definition for energy system resilience as:

Resilience is the capacity of an energy system to tolerate disturbance and to continue to deliver affordable energy services to consumers. A resilient energy system can speedily recover from shocks and can provide alternative means of satisfying energy service needs in the event of changed external circumstances.

The availability of energy has an impact on manufacturing, technology, transport, commerce, trade and the production of most goods and services. Sufficient fuel and infrastructure capacity are necessary to ensure continuity of services; to avoid unacceptable levels of interruption to physical supply, and excessive costs to the economy from unexpectedly high or volatile prices. In effect, the economic, financial and trade systems of each nation-state are underpinned by secure energy and resilient sources, production, and supply of energy. From an holistic perspective, an insecure energy system would have a negative effect on the general quality of life and well-being of civil society - the public health system; food production, processing and distribution, transportation; and the environment. Therefore the energy systems

\footnotetext{
${ }^{6}$ B. K. Sovacool, (2011), 'Introduction: Defining, Measuring and Exploring energy Security', in B. K. Soovacool (ed), The Routledge Handbook of energy Security', Londone \& New Yorl, routledge, at pp3-6.

7Winzer, (2012), 'Conceptualizing Energy Security', pp. 42-43.

${ }^{8}$ International Energy Agency (2013), Energy Security 2012, International Energy Agency, Paris, paragraph 1. 9D. Yergin, (2006), 'Ensuring Energy Security', in Foreign Affairs, Vol 85, Issue 2, pp. 69-82.

${ }^{10}$ M. H. Brown, C. Rewey, T. Gagliano, (2003), Energy Security, National Conference of State Legislatures, Washington DC, p.7.

${ }^{11}$ M. Chaudry, P. Ekins, K. Ramachandran, A. Shakoor, J.Skea, G. Strbac, X. Wang, J. Whitaker, (2009), Building a Resilient UK Energy System, Report UKERC/WP/ES/2009/023, UK Energy Research Centre, London, p.iv.
} 
need to be resilient so that, in turn, civil society is resilient and human security is enhanced. However, as asserted by Sovocool ${ }^{12}$, although the energy crises of the 1970 s catalysed global efforts to improve energy security, the opposite is occurring and energy security continues to worsen. This view is supported by the ongoing tensions and uncertainties associated with the energy situation experienced by a number European nation-states which are discussed below.

\section{Geopolitics of energy}

The transnational nature of energy implicitly presents complex geopolitical implications for nation-states. The energy security policies of individual nation-states have an impact on relationships with others and on the way transnational security infrastructures - such as exploration, pipelines, transportation and storage facilities, maritime routes, and processing plants, are managed. Energy policies can also affect civil society in unexpected ways, for example, freedom of information, because those policies may dictate who can have access to information about energy infrastructure and under what circumstances.

The geographical dimensions of energy supply and demand have changed and these changes have affected energy security and the role of the energy community as it adjusts to changing geopolitical influences. As noted by Bradshaw ${ }^{13}$, the geopolitics of global energy security relate to the influence of geographical factors, such as the distribution of centres of supply and demand, on state and non-state actions to ensure adequate, affordable and reliable supplies of energy. Previously, the energy sector was defined by US dependence on imported oil, the European Union's overreliance on natural gas imports from Russia, and China's strategy of seeking equity oil in Africa. However, there was a global shift at the beginning of the 21st century regarding the location of energy production and demand growth. According to the International Energy Agency ${ }^{14}$, the world's largest oil producers are Saudi Arabia, Russia and the United States. This shift has also seen a growing consumer market for energy in Asia and an increasing demand in emerging markets, such as China and India. According to Malik ${ }^{15}$, the rate of energy consumption growth for India will increase to $132 \%$; in China and Brazil, demand will grow by $71 \%$, and in Russia by 21\%. These changes present major geopolitical challenges to the energy importing economies, particularly those that have limited alternative forms of energy.

\section{Risks and threats to the energy system}

Risks and threats to the resilience of the energy system can take many forms and can occur suddenly. Sources of vulnerability include technical risks such as infrastructure failure but actions by nation-states and non-state actors can also threaten supply either indirectly, such as in situations of political instability, or directly, for example, by sabotage, acts of terrorism, or specific issues motivated activities, such as anti-exploration or mining demonstrations and actions. Environmental and climatic sources of risk to the security of energy can arise from natural hazards and disasters.

\footnotetext{
${ }^{12}$ B. K. Sovacool, (2012), Energy security: challenges and needs. WIREs Energy Environ., Vol 1, Issue 1, pp. 5159, p.58.

13M. Bradshaw, ( 2009) 'The Geopolitics of Energy Security,' Geography Compass, Vol 3, Issue 5, pp1920-1937 14International Energy Agency, (2014), 2014 Key World Energy Statistics, International Energy Agency, 11, 14. 15M. Malik, \& Institute of Strategic and International Studies (Malaysia). (2008), The geopolitics of energy insecurity. Kuala Lumpur, Malaysia : Institute of Strategic and International Studies.
} 
Other sources of risks, threats and vulnerabilities can be the result of unreliable stores of, or access to, energy resources, such as in unstable geopolitical areas. Volatility of the geopolitical energy system can have significant and unexpected consequences. For example, the major oil production facility in Abqaiq in Saudi Arabia was the target of a terrorist attack in 2006. The attack took place at a time of continued instability in Iraq, uncertainty regarding the Iranian nuclear issue, and ongoing violence and supply disruption in Nigeria. As noted by Al-Rodhan ${ }^{16}$, Abqaiq is significant for two reasons. First, it contains one of the largest oil fields in the world and its facilities are the main oil processing centres for Arabian Extra Light and Arabian Light crude oils, with a capacity of more than seven million barrels a day. The facilities include pumping stations, gas-oil separator plants, and pipelines. Consequently, Abqaiq is pivotal not only for Saudi Arabia's export capacity, but also for global energy production and supply.

Following the 2006 attack on the Abqaiq facility and instability elsewhere, there was increasing concern about volatility in world oil prices together with increased risks to energy security arising from higher demand, tighter supply, terrorism and political instability in energy producing and transit nation-states. The foreign policy stances of a number of nation-states were influenced, and possibly constrained, by dependence on imported oil from other nation-states.

Several key maritime choke points ${ }^{17}$ are critical for the global energy transport system and, as a consequence, they are potentially vulnerable to disruption. For the transport of oil, the most important maritime transit zones are the Strait of Hormuz and the Straits of Malacca and Singapore. Emerson and Stevens ${ }^{18}$ estimate oil transit through the Strait of Hormuz to be between 15.5 million barrels per day (bpd), and through the Straits of Malacca and Singapore to be between 13.6 million bpd and 15 million bpd, respectively. The security of maritime choke points ultimately rests on the observance of international law, and on the willingness and capacity of interested members of the international community to enforce it if necessary. Consequently, there is an imperative to maintain the rule of law across the global commons. The United Nations Environment Programme (UNEP) describes 'global commons' as resource domains or areas that lie outside of the political reach of any one nation state. Thus international law identifies four global commons namely: the High Seas; the Atmosphere; Antarctica and Outer Space. These areas have historically been guided by the principle of the common heritage of humankind - the open access doctrine or the mare liberum (free sea for everyone) in the case of the High Seas. Yet, Iran has threatened to block the Strait of Hormuz on more than one occasion. In July 2012 Aljazeera reported Iran state media quoting General Hasan Firouzabadi who said, "We do have a plan to close the Strait of Hormuz"19.

The implications and consequences of a vulnerable energy supply system affects civil societies in many ways. For example, in addition to the macroeconomic impact of the high prices for oil in 2007-08 there were civil demonstrations and protests in France,

\footnotetext{
${ }^{16}$ K. R. Al-Rodhan, (2006), The Impact of the Abqaiq Attack on Saudi Energy Security, Center for Strategic and International Studies, Washington DC.

${ }^{17}$ Note: Other key maritime chokepoints are the Straits of Malacca and Singapore, Bab Al-Mandab, the Suez Canal, and the Turkish Straits.

${ }^{18}$ C. Emmerson, P. Stevens, (2012), Maritime Choke Points and the global energy System: Charting a Way Forward, EERG BP 2012/o1, Chatham House, London, p.3.

19Aljazeera, (2012), 'Iran Will 'block' Strait of Hormuz if Pressed', 8 July 2012, Aljazeera Online, at

http://www.aljazeera.com/news/middleeast/2012/07/2012789645779519.html; accessed 12 July 2012.
} 
Spain, Portugal and Italy ${ }^{20}$. The impact of the price increase went beyond motorists and there was a negative impact on the wider transportation sector, agriculture and the fishing industries. Protesters blockaded the Channel port of Le Havre and hundreds of farmers blocked oil terminals near the cities of Dijon and Toulouse. The governments of Spain, Portugal, and Italy were pressed by protesters to provide subsidies to the fishing industry to address the gap between high oil prices and low fish prices ${ }^{21}$. Protests also targeted the European Union Fisheries Commission to address the high cost of fuel. The global recession in 2008 subsequently saw oil prices drop from US $\$ 147$ to US\$32 per barrel over a period of five months from July to December ${ }^{22}$.

The above examples highlight the vulnerability and fragility of the international energy supply sector and demonstrate the impact of energy security issues on foreign relations between nation-states and the consequences for civil societies. They also underscore the argument that the energy system needs to be resilient, but the resilience is impacted by the extent of risk to energy. Security is concerned with risks and perception of risk. Similarly, the way energy security is framed and interpreted depends on the different forms of risk and threat sources, and their respective impact measures. Accordingly, each nation-state must assess its own level of energy security against these challenges and thereby determine its own level of energy resilience. As demonstrated below, a common energy position across the EU cannot be achieved while there is fragmentation of energy security for each member state.

\section{European Energy and its Security}

The world energy consumption has doubled in the period from 1970 until the beginning of the 21st century. According to forecasts, it will increase by more than sixty per cent by the year $2030^{23}$. This increased energy demand will heighten pressure on the resilience of the global energy system. The vulnerability of energy supplies is highlighted by a review of the energy situation of the European Union (EU) where its total import dependence is reported to be $82.6 \%$ for oil and $60.3 \%$ for natural gas, with different levels of dependence for each member nation-state 24 . The fact that a significant number of nation-states depend on their energy supplies to transit through other nation-states - including states outside the EU - presents an additional risk and is a source of vulnerability not only for the individual nation-state but to the overall resilience of the European energy system.

Russia is the EU's leading supplier of crude oil, accounting for thirty-four per cent of EU imports in 2010. In addition, the EU imports significant volumes of refined products from Russia, especially diesel oil. Notwithstanding its dependence on gas, oil is still the EU's first source of energy. Conflicting energy demand forecasts add to the challenges of planning future European energy security. For example, according to the IEA's ${ }^{25}$ policy scenario, in line with a global trend of reduction in the share of oil in the global energy balance, its share in the EU's primary energy demand is

\footnotetext{
${ }^{20}$ Reuters (2008), 'Fishermen, Police Clash in EU Fuel Protest Source', in The Epoch Times, 2008. ${ }^{21}$ BBC News, (2008), 'Europe Fuels Protests Spread Wider', (30 May 2008), at http://bbc.co.uk/go/pr/fr//2/hi/europe/7426971.stm

${ }^{22}$ R. Tuttle, O. Galal, (2010), Oil Ministers See Demand Rising, Price May Exceed \$85, Bloomberg, New York.

${ }^{23}$ European Union. Doc. SEC. (2006). 317/2, 3-4.

${ }^{24}$ Comolli, (2010), 'Energy Security' p.186.

25IEA, (2011), WEO 2011, New Policies Scenario.
} 
anticipated to decrease in coming decades from thirty-five per cent in 2008 to twenty-nine per cent in 2035. Potentially, this could lead to a reduction in oil consumption in the EU by eleven per cent. However, according to a European Commission report, because of declining domestic production, the EU anticipates a growing dependence on oil imports, from eighty-two per cent in 2005 to ninety-four per cent in $2030^{26}$.

Europe relies on Russia for most of its gas supply and for a significant amount of oil. Most of the oil imported by Belarus from Russia is refined and shipped to European nation-states. Belarus ships 400,000 barrels of oil per day westward via Russia's Druzhba pipeline. Germany relies on Belarus for more than a tenth of its oil needs, and three-quarters of Poland's consumption comes from the Belarusian spur of the pipeline. Generally, refineries in Belarus hold a week's worth of oil ${ }^{27}$ and the energy dispute between Russia and Belarus in 2007 had serious implications for recipient states in Europe. At the time, the German Economy Minister, Michael Glos ${ }^{28}$, is reported to have stated that the dispute showed that "one sided dependencies must not be allowed to develop". Such concerns remain valid and highlight a significant vulnerability not only of the European energy system, but also for nation-states outside Europe which depend on imported fuel.

The extent of European reliance on Russia, and the ability of Russia to use its position for economic, trade, and political leverage, can be demonstrated in another example. At the beginning of 2015 the Russian state energy giant Gazprom cut supplies to and through Ukraine amid accusations that its neighbour has been siphoning off and stealing Russian gas. Due to these "transit risks for European consumers in the territory of Ukraine", Gazprom cut gas exports to Europe by sixty per cent, plunging the continent into an energy crisis 'within hours'29. Approximately forty per cent of Russia's gas exports to Europe and Turkey travel through Ukraine's Soviet-era network. However, Gazprom reportedly plans to send 63 billion cubic meters through a proposed link under the Black Sea to Turkey, fully replacing shipments via Ukraine ${ }^{30}$. This proposed diversification strategy may enhance Russia's energy system but it may prove to have long-term detrimental implications for the energy security of EU nation-states.

The tension between Ukraine and Russia has been ongoing over a number of years. Earlier, in March 2014, Russia threatened to cut off vital natural gas shipments over allegedly unpaid bills as part of its dispute over Crimea. In August 2014, the tensions between Russia and Ukraine continued and extended to involve other nation-states such as the US and the EU. Prior to that, in January 2009 the Russian Gazprom and the Ukrainian Naftohaz Ukrainy failed to agree on price levels for that year. The subsequent deliberate disruption to the gas supply by Russia affected twelve EU member-states and six non-EU nation-states, including those that rely almost entirely on gas supplies from Ukraine such as Bulgaria and the Republic of

\footnotetext{
26European Commission, (2013) Roadmap EU-Russian Energy Cooperation until 205o, Brussels, p.17. ${ }^{27}$ T. Webb, (2010),' Dispute Looms as Russia Suspends Belarus Energy Supplies', in The Guardian online, at http://www.guardian.co.uk/business/2010/jan/o3/russia-suspends-belarus-energy-supplies ${ }^{28}$ A. Rodriguez, (2007), 'Fuel Spat Worries Europe', in Chicago Tribune, 9 January 2007.

29Durden, T., Hedge, Z., (2015), 'EU Energy Crisis: Russia Cuts Off Gas Supplies through Ukraine To Six European Countries', Centre for Research on Globalization, Montreal at http://www.globalresearch.ca/euenergy-crisis-russia-cuts-off-gas-supplies-through-ukraine-to-six-european-countries/5424848 30Mazneva,E, (2015), 'Transit to Turkey as EU Cries Foul', Bloomberg Business, 15 January 2015.
} 
Slovakia ${ }^{31}$. The Eastern European nation-states are the most vulnerable to security of supply. This is primarily due to their over dependence on a single supplier and the relatively weak integration of their transmission systems with the rest of Europe ${ }^{32}$. Nonetheless there are options that could be investigated to reduce the dependency. For example, nation-states in central Europe and Turkey could include a combination of LNG supplies and pipeline gas from Azerbaijan. The highly dependent nation-states of the Baltic region and south-eastern Europe would also benefit further by adopting this approach which would decrease levels of vulnerability to supply interruptions and could possibly substantially reduce and even eliminate imports33.

The EU imports a significant amount of oil, natural gas, uranium, and coal from Russia and while the EU-Russia Energy Dialogue has been established to provide the overall structure for energy cooperation between the EU and Russia going forward, the vulnerability of EU oil dependent nation-states highlights their reduced resilience. The Russian government in its 2030 Energy Strategy announced a continuation of its diversification policy for oil exports. The Strategy document notes that the share of Russian exports to the Asian countries would grow from six per cent to between twenty-two to twenty-five per cent in 203034. Indeed, Russia continues to extend its oil export capability through the development of the East Siberia-Pacific Ocean (ESPO) oil pipeline. In 2012, ESPO transported thirty million tonnes of oil, including fifteen million tonnes to China. Fisher 35 noted that at the beginning of 2013 the key recipients of Russian oil from ESPO were Japan (31\%), China (24\%), the USA (22\%), together with South Korea, Singapore, the Philippines, Thailand and Malaysia. Prior to the completion of the pipeline, Kononczuk ${ }^{36}$ forecast that diversification of Russian oil to Asian markets would cause an increase in its price on the European market.

The above overview of the European energy situation highlights a particular vulnerability of the European energy system through over-reliance on external suppliers and underscores such dependency as an inhibitor of resilience.

\section{Enablers and inhibitors of a resilient energy system}

As a result of the volatility of the geopolitical energy system, with particular reference to disruptions to the reliability of energy supplies from traditional sources, such as the Middle East, nation-states have sought to increase resilience, and therefore the security of their energy. An enabler of a resilient energy supply is to build in redundancies and to ensure vulnerabilities are minimised. The IEA has set out guidelines and requirements for member states as a means to mitigate energy vulnerabilities as part of its emergency response mechanisms which were set up

${ }^{31}$ Comolli, (2010), 'Energy Security', p.180.

${ }^{32}$ Clingendael International Energy Programme, (2014), 'Russian Gas Imports to Europe and security of supply Fact sheet', at http://www.clingendaelenergy.com/files.cfm?event=files.download\&ui=9C1DEEC1-5254-00CFFD03186604989704

33R. Dickel, E. Hassanzadeh, J. Henderson, A. Honoré, L. El-Katiri, S. Pirani, H. Rogers, J. Stern, K. Yafimava, (2014), Reducing European Dependence on Russian Gas: distinguishing natural gas security from geopolitics, Oxford Institute for Energy Studies, OIES Paper NG 92, Oxford.

34European Commission, (2013), Roadmap EU-Russian Energy Cooperation until 2050, Brussels, p.17.

35E. Fisher, (2013), 'Completion of the ESPO Oil Pipeline Connects Siberia to the Pacific Ocean', in Centre of

Eastern Studies, p.1.

${ }^{36}$ W. Kononczuk, (2008), 'The East Siberia/Pacific Ocean (ESPO) Oil Pipeline: A Strategic project - An

Organisational Failure?', in Centre for Easter Studies Commentary, Issue 12, pp 1- 5, p.3. 
under the 1974 Agreement on an International Energy Programme. Before becoming a member state of the IEA, a candidate state must be a member country of the OECD and demonstrate, among other things, that as a net oil importer, it has reserves of crude oil and/or product equivalent to a minimum of ninety days of the prior year's average net oil imports. It is a requirement of the IEA regarding access to those oil reserves that:

the government (even if it does not own those stocks directly) has immediate access should the Co-ordinated Emergency Response Measures (CERM) - which provide a rapid and flexible system of response to actual or imminent oil supply disruptions be activated 37 .

In additional to the IEA emergency response mechanisms, many nation-states have sought other sources of supply and forms of energy as a means to achieve greater security and, in doing so, to meet obligations to improve energy efficiency and help reduce carbon emissions.

Diversification of energy sources can enable a nation-state's resilience to external shocks. Exploration of alternative forms of energy have gained some traction in Europe, for example the European Wind Energy Agency 38 forecasts that by 2020 wind power would produce $14-17 \%$ of the EU's electricity and this would assist in achieving the EU goal of having a twenty per cent share of its gross final energy consumption from renewable sources by $2020^{39}$.

In some instances, the location of new sources of energy has heightened vulnerabilities and increased risks due to geopolitical unrest including in transit nation-states; or the unproven nature of sources of supply. Similarly, unconventional sources of energy can potentially be either an enabler or an inhibitor of energy resilience, and can present different security challenges. For example, hydraulic fracturing has been identified by some nation-states as an enabler of energy security and supply by reducing dependency on imported energy. However other nation-states have not adopted hydraulic fracking because of reports of unwanted side effects.

The US has developed strategies to reduce its oil dependency including through the adoption of the controversial extraction procedures known as 'fracking' 40 , but this extraction technology has had less take-up in Europe. Banerjee ${ }^{41}$ reported on an internal US Environmental Protection Agency (EPA) report citing pollution of several wells caused by fracking. The EPA report reputedly found that the wells were contaminated with methane, and substances such as manganese and arsenic. Published research from the University of Texas in 2013 found elevated levels of arsenic and heavy metals in ground water near natural gas fracking sites in that

\footnotetext{
37International Energy Agency, (2013), Energy Policy in IEA Countries: Australia 2012, International Energy Agency, Paris.

${ }^{38}$ European Wind Energy Agency (2014), Statistics and Targets,

http://www.ewea.org/fileadmin/swf/factsheet/1_statisticsandtargets.pdf

39Eurostat,( 2015), 'Renewable energy statistics', http://ec.europa.eu/eurostat/statisticsexplained/index.php/Renewable_energy_statistics

${ }^{40}$ Note: Hydraulic fracturing, or 'fracking', is the process of drilling and injecting fluid into the ground at a high pressure in order to fracture shale rocks to release natural gas inside.

${ }^{41}$ N. Banerjee, (2013), 'Internal EPA Report Highlights Dispute over Fracking and Well Water', in LA Times online, 27 July 2013, at latimes,com/news/nationworld/nation/la-na-epa-dimock-20130728,0,4847442
} 
state's Barnett Shale. Other concerns have centred on the release of methane gas into the atmosphere from fracking sites ${ }^{42}$. Studies, including those by Fontenot el al 43 contribute to the controversy surrounding hydraulic fracking and unconventional energy sources and have in turn influenced political leaders.

Environmental and political concerns have led to moratoriums in several European nation-states and the oil-price slump has meant that exploration is a less economic proposition and more expensive where the geology has proven complex. France has the most potential for unconventional hydrocarbons in mainland Western Europe. The shales of the Paris Basin are estimated to have major shale gas and minor shale oil potential, while the Jurassic shales in the south-east of the country may also have some shale gas potential. But a fracking moratorium has been in place since 2011, and was upheld in 2013. Similarly, Germany has not permitted fracking since 2011 although it does not have significant quantities of prospective shale. The only other mainland western European nation-state with significant shale gas potential is the Netherlands. However, no fracking for shale gas has been permitted44. Although there has been a moratorium on fracking in Denmark since 2012, the government has allowed some exploration in Jutland and Zealand.

In Eastern Europe, Bulgaria placed a moratorium on fracking in 2012. While Poland has been keen to exploit any potential shale by fracking and consequently to reduce its dependence on gas supplied from Russia, hydraulic fracking has yet to prove to be economically viable there. The political instability in the Ukraine has determined that no fracking will occur in the Donetsk region in the indeterminate future.

The promotion and support for fracking moratoriums and bans means ongoing dependence on Russia for energy supply. Yet such bans continue across many EU countries with little regard for the resilience of energy supply arising from Russia's past actions of interrupting energy supplies to European nation-states and the potential for it to continue such practice in the future.

While there are widespread concerns about fracking, its potential significance and the possible implications for European nation-states have been recognised. In one example, approximately $€ 12$ million has been provided in 2015 to assess the environmental impact of the controversial technique and this may assist in identifying options to reduce vulnerability and to increase energy resilience by investigating the impact of shale gas exploitation and fracking 45 . However, the outcome of the research will not be known for some time and the moratoriums remaining in place confirm the dependency on Russia for energy supplies.

There has been some increased implementation of measures to ensure the security of gas supply and to achieve a higher degree of preparedness by most European

\footnotetext{
42Note: Methane acts as a greenhouse gas about twenty times as potent as carbon dioxide according to the EPA. 43B. Fontenot, L.R. Hunt, Z. L. Hildenbrand, D. D. Carlton Jnr, H. Oka, J. L. Walton, D. Hopkins, A. Osorio, B. Bjorndal, Q. H. Hu, K. A. Schug, (2013), 'An Evaluation of Water Quality in Private Drinking Water Wells Near Natural Gas Extraction Sites in the Barnett Shale Formation', in Environmental Science and Technology, Vol 47, Issue 17, pp 10032-10040.

${ }^{44}$ L. Herringshaw, (2015), 'Whatever happened to the great European fracking boom?', The Conversation, 11 march 2015, at http://theconversation.com/whatever-happened-to-the-great-european-fracking-boom-38550 45E. Kelly, (2015), 'EU announces around $€ 12$ million in funding for fracking research', Science Business, 25 February 2015, at http://www.sciencebusiness.net/news/76921/EU-announces-around-\%E2\%82\%AC12-millionin-funding-for-fracking-research
} 
member states. However, the lack of cohesion among European nation-states regarding energy security has assisted Russia gain favourable energy terms through bilateral arrangements and this strategy has heightened dependence on Russian supplies. While energy security has, to some degree, been formalised through Article 194(1) of the Treaty on the Functioning of the European Union (TFEU or 'Lisbon Treaty' $)^{46}$, there is no legal obligation on the member states. Consequently solidarity between them has been absent - or at best, inconsistent.

The EU's 2007 'Energy Action Plan' declared common energy policy has been proven to be an inadequate strategy to cope with the new global and geopolitical challenges. 'An Energy Policy for Europe' attempted to bring together all the elements and to present a vision for the future of energy in Europe but a number of environmental organisations across Europe criticised the Commission for not adopting the measures necessary to achieve the stated objectives. Since then, pressure has mounted to address the fragmented energy policies across the EU and at the EU summit in March, 2015, leaders agreed they wanted to create a single energy market, in part to reduce the bloc's reliance on oil and gas from Russia. The energy union envisaged by the heads of state and government from the EU's twenty-eight members would also seek to increase transparency in the gas market, improve energy efficiency and help reduce carbon emissions.

While this paper is not focused on forms of renewable energy it is worth noting that renewables provided fifteen per cent of the EU's energy in 2013, according to data published by Eurostat47, the EU's official statistical body. The figures show the EU is on course to meet its twenty per cent renewables target in 2020, although the UK is behind its 2020 renewable energy target. Specifically, transport and heat are lagging behind progress in electricity, where wind and solar remain relatively small contributors. Notwithstanding such progress, the Oxford Institute for Energy Studies ${ }^{48}$ research indicates that it will provide limited scope to reduce significantly European overall dependence on Russian gas before the mid-2020s.

\section{Conclusion}

This paper has set out to establish that while there is an ongoing dependency on traditional forms of energy such as petroleum and gas, their respective energy systems need to be resilient. Energy security adds to the complexity of foreign policy stances of individual nation-state and frames relationships between nation-states particularly where there is a dependency on other states for sources of energy and its supply. Energy supply security has become a key concern for European nations and the European Union, and their energy systems face a number of factors which can enhance or inhibit the resilience of those systems.

Energy systems need to be resilient so that, in turn, civil society is resilient and human security is enhanced now and in the future. However, to date, European energy security policy has been fragmented with the result that it has not been as

\footnotetext{
${ }^{46}$ J. Braun, (2011) 'EU Energy Policy Under the Treaty of Lisbon Rules: Between a New Policy and Business as Usual', EPIN Working Paper No. 31, February 24, 2011.

47 Eurostat, (2015), 'Share of energy from renewable sources', http://ec.europa.eu/eurostat/web/productsdatasets/-/nrg_ind_335a

${ }^{48}$ R. Dickel, et al, (2014), Reducing European Dependence on Russian Gas: -, Oxford Institute for Energy Studies, OIES Paper NG 92, Oxford.
} 
effective as desired. It has not been successful in achieving robust infrastructure and other elements to enhance the security of Europe's energy supply. To a large extent this situation has been driven by a lack of solidarity as part of a common foreign energy policy. Without effective measures the energy system will be less secure and will continue to lack resilience.

A resilient energy system can speedily recover from shocks and can provide alternative means of satisfying energy service needs in the event of changed external circumstances. It is apparent that in most instances the energy supply system across Europe would fail to meet that definition because the energy systems of individual European nation-states are uneven and a number of vulnerabilities are evident through supply dependencies, due to the adoption of few effective alternative energy forms.

As major energy consumers, European nation-states face a number of challenges to address future energy needs and to increase the resilience of their energy supply. Among these challenges are the ongoing instability in energy producing regions such as the Middle East, risks of interruptions to energy supply by Russia, rapidly rising global demand and competition for energy resources from emerging economies such as China and India, a fragmented internal European energy market, the uncertainty of alternative energy options such as fracking, and the imperative to change the energy mix to address climate change policy issues. Actively addressing energy security in a collaborative way will help to achieve a more resilient energy system for the future. 